\title{
THE SECRETION OF URINE BY PREMATURE INFANTS
}

\author{
BY \\ W. F. YOUNG, M.B., D.C.H., J. L. HALLUM, M.D., and \\ R. A. MCCANCE, M.D., F.R.C.P.
}

(From the Children's Hospital and the Sorrento Maternity Home, Birmingham, and the Department of Medicine, Cambridge)

Previous work on the secretion of urine by full-term newborn infants has shown that their kidneys function rather differently from those of adults (McCance and Young, 1941). Premature infants have now been investigated because it was thought that the differences in function might be even greater at the earlier stages of development. Several oedematous infants have been included in the investigations, since Hallum's (1941) work suggested that had this not been done the work would have been incomplete. This author found that in a large series of infants 13.4 per cent. of those with a maturity of less than thirty-six weeks at birth developed 'oedema of the newborn,' whereas only 1.2 per cent. of those born at or nearer full term showed any sign of it. In Hallum's series the oedema always appeared within two or three days of birth, usually in the lower limbs, face, hands and genitalia. It was transient as a rule and subsided in about a week, but less frequently it progressed to generalized anasarca. Oedema of the lungs and of the larynx was sometimes observed in the later stages. The etiology is obscure and the literature not helpful. Hallum made a partial study of the blood chemistry and found that oedematous infants usually had high blood ureas. The range was 36 to $140 \mathrm{mgm}$. per 100 c.c. and the average $67 \mathrm{mgm}$. per 100 c.c. as against the ' normal 'limits of 21 to $39 \mathrm{mgm}$. per 100 c.c. (Strictly speaking no premature infant can be regarded as normal, but in this article the infants who did not have oedema have been so designated.) The urine was noted to be scanty and 86 per cent. of the specimens contained a trace of albumin. This last, however, was not considered pathological, as von Reuss (1913) had found that 96 per cent. of the infants examined by him had albuminuria during the first four days of life. Histological examination of the kidneys of oedematous infants revealed no abnormality.

\section{Material and methods}

Infants admitted to the Municipal Premature Infant's Ward, City of Birmingham, were the subjects of the investigation. Their ages ranged from 
two to eighteen days and their maturity was estimated to be thirty to thirty-six weeks. Both oedematous and 'normal' infants were tested during the first week of life. Some babies were tested again when they were about a week older; several of these had had oedema when first examined and had lost it during the interval.

Plasma protein was estimated by the micro-Kjeldahl method (Peters and Van Slyke, 1932). The collection of blood and urine and all chemical determinations other than that of plasma protein were made in the way described by McCance and Young (1941). There have been, however, a few female subjects in this investigation, and they voided their urine into small enamel bowls instead of hard glass test tubes. This was found to be satisfactory as premature infants are almost immobile and are nursed entirely in their cots. The error in the timing of each specimen was never greater than five minutes.

\section{Results}

The serum chemistry. Table 1 shows the serum chemistry of nineteen premature infants aged two to seven days, of whom seven were oedematous

TABLE 1

SERUM CHEMISTRY OF PREMATURE INFANTS

\begin{tabular}{|c|c|c|c|c|c|}
\hline SUBJECT & $\begin{array}{c}\text { AGE } \\
\text { IN } \\
\text { DAYS }\end{array}$ & $\begin{array}{c}\text { UREA } \\
\text { MGM. PER } \\
100 \text { C.C. }\end{array}$ & $\begin{array}{c}\text { Na } \\
\text { MGM. PER } \\
100 \text { C.C. }\end{array}$ & $\begin{array}{c}\text { Cl } \\
\text { MGM. PER } \\
100 \text { C.C. }\end{array}$ & $\begin{array}{l}\text { PROTEINS } \\
\text { GM. PER } \\
100 \text { C.C. }\end{array}$ \\
\hline \multicolumn{6}{|c|}{ Group I. 'NormaL' INFANTS AGED 3-5 DaYs } \\
\hline $\begin{array}{l}\text { Aa } \\
\text { Ws } \\
\text { Bs } \\
\text { Hu } \\
\text { C } \\
\text { Bt } \\
\text { R } \\
\text { Dy } \\
\text { Sm } \\
\text { St } \\
\text { E } \\
\text { Bg }\end{array}$ & $\begin{array}{l}3 \\
3 \\
3 \\
3 \\
3 \\
4 \\
4 \\
4 \\
4 \\
4 \\
5 \\
5\end{array}$ & $\begin{array}{l}17 \cdot 0 \\
41 \cdot 0 \\
15.0 \\
14 \cdot 8 \\
22 \cdot 5 \\
29 \cdot 5 \\
99 \cdot 6 \\
39 \cdot 0 \\
39 \cdot 2 \\
27 \cdot 0 \\
10.0 \\
30.7\end{array}$ & $\begin{array}{l}348 \\
345 \\
- \\
340 \\
353 \\
326 \\
342 \\
300 \\
293 \\
346 \\
358 \\
342\end{array}$ & $\begin{array}{l}368 \\
377 \\
318 \\
368 \\
359 \\
385 \\
385 \\
-380 \\
415 \\
386 \\
348\end{array}$ & $\begin{array}{l}5 \cdot 27 \\
4 \cdot 86 \\
5 \cdot 36 \\
4 \cdot 00 \\
5 \cdot 11 \\
5 \cdot 15 \\
4 \cdot 18 \\
4 \cdot 27 \\
4 \cdot 14 \\
4 \cdot 83 \\
3 \cdot 62 \\
4 \cdot 71\end{array}$ \\
\hline \multicolumn{6}{|c|}{ Group II. OEDEmatous INFANTS AGED 2-7 Days } \\
\hline $\begin{array}{l}\text { Hs } \\
\mathbf{L} \\
\mathbf{B l} \\
\mathbf{X} \\
\mathbf{Y} \\
\mathbf{M} \\
\mathbf{W e}\end{array}$ & $\begin{array}{l}2 \\
2 \\
2 \\
4 \\
4 \\
4 \\
7\end{array}$ & $\begin{array}{r}90.0 \\
51 \cdot 0 \\
103.6 \\
120.0 \\
132.0 \\
56.5 \\
30.2\end{array}$ & $\begin{array}{l}340 \\
350 \\
371 \\
- \\
- \\
- \\
408\end{array}$ & $\begin{array}{l}397 \\
342 \\
386 \\
- \\
- \\
390 \\
347\end{array}$ & $\begin{array}{l}3 \cdot 73 \\
4 \cdot 55 \\
4 \cdot 5 \\
- \\
4 \cdot 58 \\
5 \cdot 04 \\
4 \cdot 85\end{array}$ \\
\hline \multicolumn{6}{|c|}{ Group III. 'NoRmaL' INFANTS AGED 8-18 DaYS } \\
\hline $\begin{array}{l}\mathbf{M} \\
\mathbf{B l} \\
\mathbf{D a} \\
\mathbf{B t} \\
\mathbf{R} \\
\mathbf{D} \mathbf{y} \\
\mathbf{S t} \\
\mathbf{L}\end{array}$ & $\begin{array}{r}8 \\
8 \\
9 \\
11 \\
11 \\
13 \\
18 \\
18\end{array}$ & $\begin{array}{r}26 \cdot 0 \\
25 \cdot 0 \\
9 \cdot 0 \\
15 \cdot 2 \\
20 \cdot 6 \\
16 \cdot 2 \\
15 \cdot 0 \\
16 \cdot 0\end{array}$ & $\begin{array}{l}332 \\
304 \\
354 \\
308 \\
304 \\
356 \\
332 \\
300\end{array}$ & $\begin{array}{l}400 \\
380 \\
371 \\
398 \\
381 \\
394 \\
386 \\
370\end{array}$ & $\begin{array}{l}4 \cdot 96 \\
3 \cdot 80 \\
5 \cdot 02 \\
4 \cdot 30 \\
4 \cdot 36 \\
3 \cdot 99 \\
4 \cdot 70 \\
4 \cdot 24\end{array}$ \\
\hline
\end{tabular}


(groups I and II); and of eight infants aged eight to eighteen days (group III). One of the last was only examined once, but the others were babies who had been tested during the first week and their previous results are recorded in groups I and II.

The blood urea of the ' normal' infants in group I varied from 10 to $99.6 \mathrm{mgm}$. per 100 c.c. and in five it was above $29 \mathrm{mgm}$. per 100 c.c. All the infants with oedema (group II) had high blood ureas except We, aged seven days, whose oedema was subsiding on the day of the tests. The blood ureas in group III ranged from 9 to $26 \mathrm{mgm}$. per 100 c.c., and these figures resemble those obtained in a series of full-term infants aged seven to fourteen days, who were shown to have an average blood urea of $16.4 \mathrm{mgm}$. per 100 c.c. (McCance and Young, 1941).

As in full-term infants, both the sodium and chloride in the serum varied much more widely from infant to infant than they usually do from adult to adult. The chlorides were sometimes high compared with adult standards, and the sodium in the serum of two oedematous infants ( $\mathrm{Bl}$ and $\mathrm{We}$ ) was above the normal adult range, and higher than that of any 'normal' infant.

The protein in the plasma of premature infants ranged from 3.62 to $5.27 \mathrm{gm}$. per 100 c.c. These figures are low by adult standards (6 to $8 \mathrm{gm}$. per 100 c.c.), but are not necessarily abnormal, for it has, been shown that the plasma proteins tend to be low until the second year of life (Mello-Leitao, 1916; Hickmans, 1940). The plasma proteins of the oedematous infants, with a range of 3.73 to $5.04 \mathrm{gm}$. per 100 c.c., were not any lower than those of ' normal' infants, and in all who were re-examined the plasma proteins had fallen a little during the interval. In Hallum's preliminary investigation, however, some oedematous infants had very low plasma proteins $(2.7$ to $4 \cdot 1$ gm. per 100 c.c.), and in several they were higher after the oedema had subsided.

The urea clearances. Fig. 1 shows the urea clearances $(\mathrm{UV} / \mathrm{P})$, of all the premature infants plotted against their minute volumes. It will be noted that: (1) The minute volumes varied from 0.005 to 0.333 c.c. per minute. (2) The urea clearances ranged between 0.025 and 2.43 c.c. per minute. (3) The urea clearances varied with the minute volumes. (4) The minute volumes, and consequently the urea clearances, were frequently low in babies with oedema, but at comparable minute volumes the clearances of oedematous infants were really no lower than those of the 'normal' infants. It is probable, therefore, that the high blood ureas of the oedematous infants were solely due to the low minute volumes. This is supported by the fact that baby $R$, who had not got oedema but was passing comparably small volumes of urine, had a blood urea of $99 \mathrm{mgm}$. per 100 c.c. After the infants had lost their oedema their minute volumes, urea clearances and blood ureas were all found to be in the 'normal' range. All the clearances will therefore be considered together when comparisons are being made with full-term babies and with adults.

In premature as in full-term infants the magnitude of the urea clearances at any particular minute volume varied considerably from one child to another 
and sometimes in the same child from day to day; nevertheless it was the rule for the clearances of each baby to increase steadily with the minute volume.

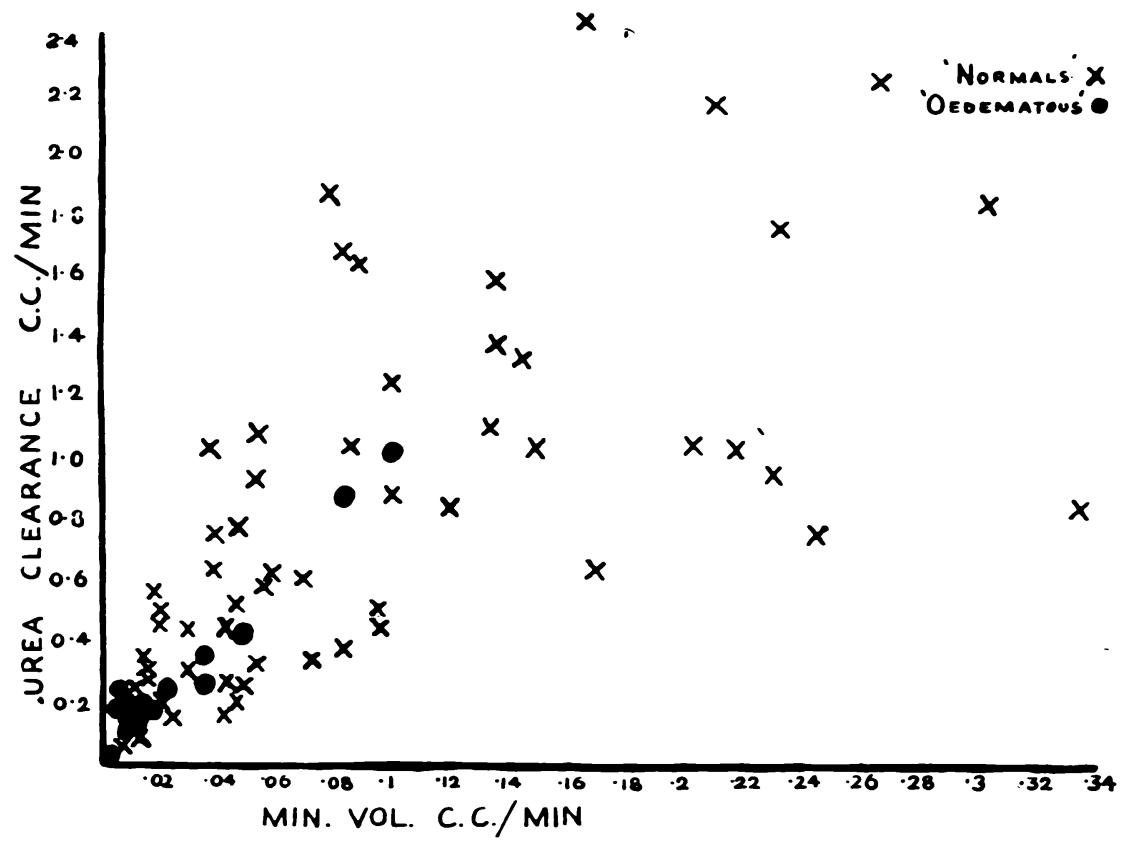

FIG. 1.-The urea clearances of ' normal' and oedematous premature infants.

In order to compare the urea clearances of premature and full-term infants the individual minute volumes and clearances were corrected for surface area. At both ages the minute volumes were separated into four groups, and the clearances and minute volumes in each group were averaged. The results, which are given in fig. 2 , show that at similar minute volumes the premature infant clearances were considerably lower than those of full-term infants. The urea clearances of the latter have already been shown to be very low compared with those of adults (McCance and Young, 1941).

In the investigation of full-term infants some inulin and urea clearances were estimated simultaneously. It was found that both varied together with the minute volume, and this has also been found to hold in infants with gastroenteritis. In all babies, therefore, it would seem that the variations in the urea clearances may be used as a guide to the behaviour of the glomerular filtration rates. If this be so the glomerular filtration rate (per metre surface area) is even lower in premature infants than it is in full-term infants and, as in them, it varies quite extensively with the minute volume. A similar association has been met with in adult rabbits at all minute volumes (Kaplan and Smith, 1935; Wilkinson and McCance, 1940), and in pump-lung-kidney preparations of the dog a change in the minute volume has also been shown to accompany the change in glomerular filtration rate brought about by a rise or fall in the arterial blood pressure (Shannon and Winton, 1940). All the evidence tends to show that in infancy the urea clearances, and 


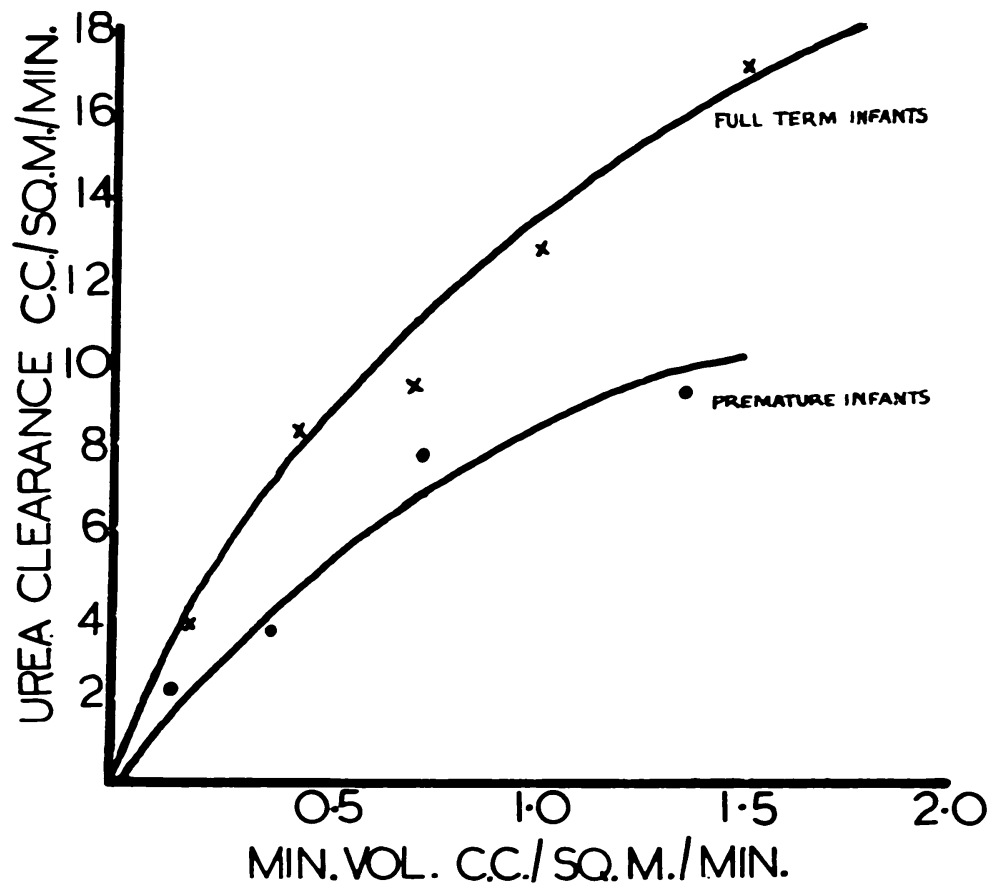

Fig. 2.-A comparison of the average urea clearances of full-term and premature infants.

hence the glomerular filtration rates, have not yet become as stable as they are in adult life.

A histological examination of the renal glomerulus in early postnatal life led Gruenwald and Popper (1940) to suggest that infants of this age might have low glomerular filtration rates. These authors observed that up to birth the glomerular loops were matted together and invaginated in a sac of high columnar epithelium. After birth the epithelial sac had burst and the loops expanded, but in early postnatal life the peaks of the loops were still covered with high columnar epithelium. Gruenwald and Popper considered that this layer might impede glomerular filtration.

The excretion of minerals. The electrolytes are threshold substances and their clearances depend upon the concentration in the serum and the reabsorptive activity of the tubules as well as upon the glomerular filtration rates and the minute volumes. The tubules are partly under the control of extrarenal factors, and the suprarenal cortex is especially concerned with sodium, chloride and potassium.

The sodium and chloride clearances, plotted against their minute volumes, are shown in fig. 3. For graphical convenience nine sodium or chloride clearances at minute volumes over $0 \cdot 2$ c.c. per minute and two exceptionally high chloride clearances above 0.02 c.c. per minute have been omitted. It will be seen that the sodium and chloride clearances tended to rise with an increase in the minute volume, but there was a wide scatter. In several infants, whose sodium clearances are plotted on the base line, the urine contained only traces 
of sodium even at fairly high minute volumes. Since the concentrations of sodium and chloride in the serum varied so much from infant to infant, the clearances at comparable minute volumes might have been expected to vary with them but, as in full-term infants, individual idiosyncrasies outweighed any such effects. Some children, for example, whose serum concentration was relatively high, had very low clearances.

Fig. 3 shows that the oedematous infants tended to have low sodium and

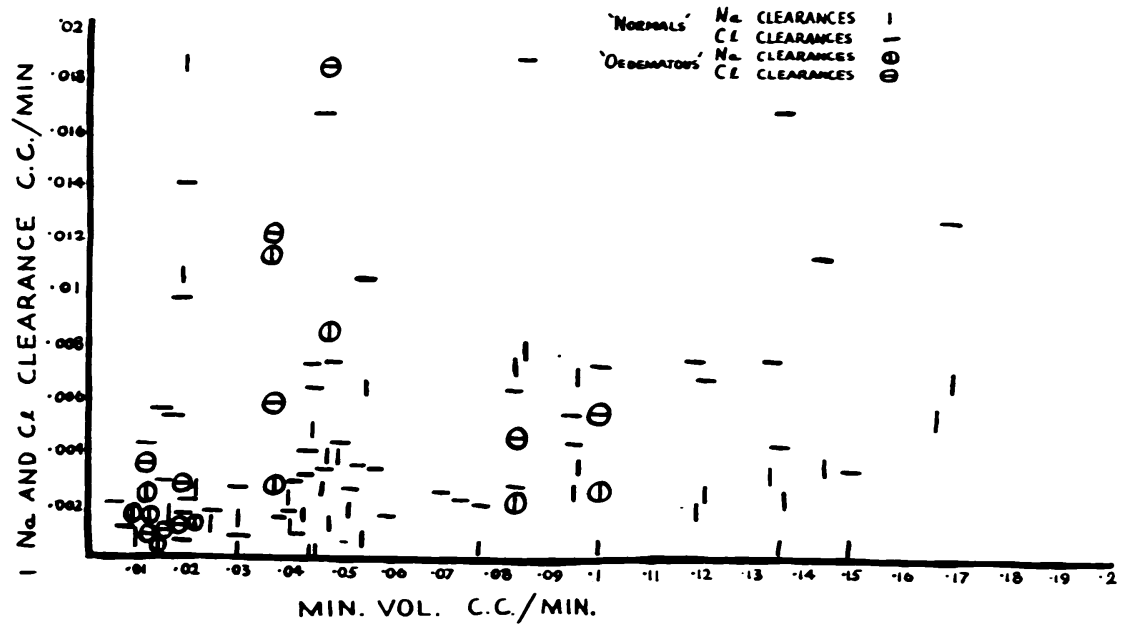

FIG. 3. - The sodium and chloride clearances of 'normal' and oedematous premature infants.

chloride clearances at low minute volumes, but that at such minute volumes the clearances of 'normal' infants were within the same range. All the clearances have therefore been included when the results were being averaged for comparison with those of full-term infants.

Few estimations of serum potassium were made, and potassium clearances could not therefore be calculated for premature infants. Since many were jaundiced at the time of the investigation, the serum level was probably high; the amount of potassium in the urine, however, was small, and the potassium clearances were probably quite as low as those of full-term infants.

The sodium, chloride and potassium clearances of full-term infants were found to be low compared with those of adults; a further comparison has now been made between the sodium and chloride clearances of full-term and premature infants. The concentrations of sodium and chloride in the sera were first averaged, and found to be the same in both groups. It was felt, therefore, that their clearances might safely be compared. Accordingly, both minute volumes and clearances were 'corrected' for surface area and averaged as the urea clearances had been. The results are given in table 2 . It is evident that not only the urea clearances, but also the sodium and chloride clearances were lower in premature than in full-term infants; moreover, the $\frac{\text { chloride }}{\text { urea }}$ and $\frac{\text { sodium }}{\text { urea }}$ clearance ratios show that the mineral clearances were relatively lower 
than the urea clearances. If it is accepted that the urea clearances follow the glomerular filtration rates, the low $\frac{\text { mineral }}{\text { urea }}$ clearance ratios in premature infants are presumably due to a relatively higher rate of tubular reabsorption per c.c. of filtrate formed.

TABLE 2

A COMPARISON OF THE UREA, SODIUM AND CHLORIDE CLEARANCES OF FULL-TERM AND PREMATURE INFANTS

\begin{tabular}{|c|c|c|c|c|c|c|c|c|c|c|}
\hline \multirow{3}{*}{$\begin{array}{c}\text { MINUTE } \\
\text { VOLUME, } \\
\text { C.C. PER } \\
\text { SQ. M. PER } \\
\text { MINUTE }\end{array}$} & \multicolumn{5}{|c|}{ FULL-TERM INFANTS } & \multicolumn{5}{|c|}{ PREMATURE INFANTS } \\
\hline & \multicolumn{3}{|c|}{$\begin{array}{l}\text { CLEARANCE, C.C. } \\
\text { PER SQ. M. PER } \\
\text { MINUTE }\end{array}$} & \multicolumn{2}{|c|}{ RATIO } & \multicolumn{3}{|c|}{$\begin{array}{l}\text { CLEARANCE, C.C. } \\
\text { PER SQ. M. PER } \\
\text { MINUTE }\end{array}$} & \multicolumn{2}{|c|}{ RATIO } \\
\hline & UREA & $\mathrm{Na}$ & $\mathrm{Cl}$ & $\frac{\mathrm{Na} \times 100}{\mathrm{U}}$ & $\frac{\mathrm{Cl} \times 100}{\mathrm{U}}$ & UREA & $\mathrm{Na}$ & $\mathrm{Cl}$ & $\frac{\mathrm{Na} \times 100}{\mathrm{U}}$ & $\frac{\mathrm{Cl} \times 100}{\mathrm{U}}$ \\
\hline $\begin{array}{l}\mathbf{0 . 3} \\
0.75 \\
1.0 \\
1.3\end{array}$ & $\begin{array}{r}5 \cdot 9 \\
11 \cdot 2 \\
13 \cdot 3 \\
15 \cdot 6\end{array}$ & $\begin{array}{l}0.048 \\
0.070 \\
0.093 \\
0.12\end{array}$ & \begin{tabular}{|l}
$0 \cdot 1$ \\
$0 \cdot 16$ \\
$0 \cdot 185$ \\
$0 \cdot 21$
\end{tabular} & $\begin{array}{l}0.82 \\
0.62 \\
0.70 \\
0.77\end{array}$ & $\begin{array}{l}1 \cdot 7 \\
1.43 \\
1 \cdot 40 \\
1 \cdot 35\end{array}$ & $\begin{array}{l}3 \cdot 5 \\
7 \cdot 0 \\
8 \cdot 3 \\
9 \cdot 2\end{array}$ & $\begin{array}{l}0.025 \\
0.035 \\
0.036 \\
0.038\end{array}$ & $\begin{array}{l}0.04 \\
0.07 \\
0.085 \\
0.105\end{array}$ & $\begin{array}{l}0.71 \\
0.5 \\
0.43 \\
0.41\end{array}$ & $\begin{array}{l}1 \cdot 14 \\
1 \cdot 0 \\
1.02 \\
1 \cdot 1\end{array}$ \\
\hline
\end{tabular}

The osmotic pressure of the urine. It was found that the osmotic pressure, i.e. the concentration of solids, in the urine of full-term infants was low by adult standards, and that the ratio-

$$
\frac{\text { m.eq. of electrolytes in the urine }+ \text { m.eq. of urea }(U)}{\text { m.eq. of electrolytes in the plasma }+ \text { m.eq. of urea }(P)}
$$

never exceeded 1 and was usually below $0 \cdot 5$, even when the urine volumes were small. This relationship has been investigated in premature infants and, as at full term, the U/P ratios tended to be of a low order. Some, however, were over 1, and higher than any of those found at full term. This was unexpected, and led to a further analysis of the data. It then became clear that there was an undoubted association between the height of the $U / P$ ratio and the concentration of urea in the blood. Baby R. showed this particularly well, for when he was first examined his blood urea was $99.6 \mathrm{mgm}$. per 100 c.c. and he had a U/P ratio of 1.1 with a minute volume of 0.34 c.c. per sq. $\mathrm{m}$. per minute. On the second occasion his blood urea was $20.6 \mathrm{mgm}$. per 100 c.c., and when his minute volume was 0.32 c.c. per sq. $\mathrm{m}$. per minute his $\mathrm{U} / \mathrm{P}$ ratio was only $0 \cdot 24$. In table 3 the blood ureas and $U / P$ ratios are set out over four limited ranges of minute volumes, and the general association of high $U / P$ ratios with high blood ureas is clear. On re-examining the $U / P$ ratios of the full-term infants, it was then found that the one child in that series who had had a high blood urea had also given a high U/P ratio. This child had a meningocoele and fever and, although the high ratio was mentioned, it was not discussed because it was felt that the child was not normal. 
THE RELATIONSHIP BETWEEN THE BLOOD UREA AND THE $\frac{\mathrm{P}}{\mathrm{P}}$ RATIO

\begin{tabular}{|c|c|c|c|c|c|}
\hline SUBJECT & BLOOD UREA & $\frac{\mathrm{U}}{\mathrm{P}}$ RATIO & SUBJECT & BLOOD UREA & $\frac{\mathrm{U}}{\mathrm{P}}$ RATIO \\
\hline \multicolumn{3}{|c|}{$\begin{array}{l}\text { (MIN. vOLS. 0.08-0.2 C.C. PER SQ. M. } \\
\text { PER MINUTE) }\end{array}$} & \multicolumn{3}{|c|}{$\begin{array}{l}\text { (MIN. VOLS. 0.08-0.2 C.C. PER SQ. M. } \\
\text { PER MINUTE) }\end{array}$} \\
\hline $\begin{array}{l}\text { Bl } \\
\text { R } \\
\text { R } \\
\text { Hs } \\
\text { Hs } \\
\text { L } \\
\text { Sm } \\
\text { Sm } \\
\text { M } \\
\text { C } \\
\\
\text { (MIN. }\end{array}$ & $\begin{array}{c}103.6 \\
99 \cdot 6 \\
99 \cdot 6 \\
90 \\
90 \\
51 \\
39 \cdot 2 \\
39 \cdot 2 \\
26.09 \\
22.5 \\
\\
\\
\end{array}$ & $\begin{array}{l}0.9 \\
1.2 \\
1.08 \\
0.79 \\
0.73 \\
0.49 \\
1.48 \\
1.79 \\
0.59 \\
0.31 \\
\\
\text { SQ. M. }\end{array}$ & $\begin{array}{l}\mathrm{L} \\
\mathrm{L} \\
\mathrm{Bt} \\
\mathrm{Bt} \\
\mathrm{Bl} \\
\mathrm{R} \\
\mathrm{R} \\
\mathrm{L} \\
\mathrm{L} \\
\mathrm{St} \\
\mathrm{Bt} \\
\mathrm{Da}\end{array}$ & $\begin{array}{l}51 \\
51 \\
29 \cdot 5 \\
29 \cdot 5 \\
25 \cdot 0 \\
20 \cdot 6 \\
20 \cdot 6 \\
18 \cdot 0 \\
18 \cdot 0 \\
15.0 \\
15 \cdot 2 \\
9.0\end{array}$ & $\begin{array}{l}0 \cdot 4 \\
0 \cdot 39 \\
0 \cdot 45 \\
0 \cdot 28 \\
0 \cdot 2 \\
0 \cdot 17 \\
0 \cdot 41 \\
0 \cdot 15 \\
0 \cdot 10 \\
0 \cdot 12 \\
0 \cdot 20 \\
0 \cdot 09\end{array}$ \\
\hline $\begin{array}{l}\mathbf{B} \mathbf{l} \\
\mathbf{R}\end{array}$ & $\begin{array}{c}\text { PER MINUTE } \\
103.6 \\
99.6\end{array}$ & $\begin{array}{l}0.69 \\
1 \cdot 1\end{array}$ & \multicolumn{3}{|c|}{$\begin{array}{l}\text { (MIN. vOLS. 1.0-2.16 C.C. PER SQ. M. } \\
\text { PER MINUTE) }\end{array}$} \\
\hline $\begin{array}{l}\text { Hs } \\
\text { Ws } \\
\text { Sm } \\
\text { Bg } \\
\text { St } \\
\text { M } \\
\text { Bl } \\
\text { R } \\
\text { Bt } \\
\text { E }\end{array}$ & $\begin{array}{l}90.0 \\
41.0 \\
39.2 \\
30.7 \\
27.0 \\
26.0 \\
25.0 \\
20.6 \\
15.2 \\
10.0\end{array}$ & $\begin{array}{l}0.73 \\
0.45 \\
0.27 \\
0.22 \\
0.41 \\
0.39 \\
0.138 \\
0.24 \\
0.27 \\
0.078\end{array}$ & $\begin{array}{l}\mathrm{Bt} \\
\mathrm{Bt} \\
\mathrm{St} \\
\mathrm{St} \\
\mathrm{E} \\
\mathrm{E} \\
\mathrm{Da} \\
\mathrm{Da}\end{array}$ & $\begin{array}{r}29 \cdot 5 \\
15 \cdot 2 \\
15 \cdot 0 \\
15 \cdot 0 \\
10.0 \\
10.0 \\
9 \cdot 0 \\
9.0\end{array}$ & $\begin{array}{l}0.16 \\
0.16 \\
0.17 \\
0.11 \\
0.07 \\
0.06 \\
0.09 \\
0.09\end{array}$ \\
\hline
\end{tabular}

The connexion between high blood ureas and $U / P$ ratios in infants is interesting from the point of view of their kidney function. The relationship would follow inevitably if the power to concentrate urea from blood to urine were unaffected by the height of the blood urea and the excretion of electrolytes. The reason is as follows: The osmotic pressure of both urine and blood can be regarded as due to electrolytes and urea, and the $\mathrm{U} / \mathrm{P}$ written $\frac{\mathrm{Ue}-\mathrm{Uu}}{\mathrm{Pe}+\mathrm{Pu}}$. The plasma osmotic pressure is due mostly to electrolytes, and the urea is never an important part. The osmotic pressure of the urine may be due almost entirely to urea, and in babies, who have usually got very low electrolyte clearances, it generally is. Hence, doubling the urea in the blood may not sensibly alter the total osmotic pressure of this fluid, but doubling the urea in the urine may practically double its osmotic pressure, and the total U/P ratio. Returning to table 3 it will be seen that baby $\mathrm{Sm}$ in the low-minute volume group has exceptionally high $U / P$ ratios with an almost normal blood urea. His high $\mathbf{U} / \mathrm{P}$ ratios, and his failure to conform to the generalization which has just been made, were due to his electrolyte clearances which were very high, and far outside the usual range.

In adults the $U / P$ ratios seldom exceeds 3 . This is, so to speak, their 
ceiling, and when that has been reached an increase in the fraction of the osmotic pressure ratio due to urea can only be achieved by a decrease in the fraction of the ratio due to electrolyte. It was at first thought that at low minute volumes the infants' kidneys were working at or about their limiting $\mathrm{U} / \mathrm{P}$ ratios for total osmotic pressure. The observations now recorded suggest that this is not so, but that the concentration of urea and electrolytes are proceeding independently of each other, and that over the serum concentrations so far encountered in these studies neither are being limited by the total osmotic pressure of the urine.

Table 3 also shows what has been implied several times before, namely, that high blood ureas in infants only occur when the minute volumes have been low. In other words at this age a low urine output spells renal failure.

\section{Causes of oedema}

The susceptibility of premature infants to oedema is extremely interesting in the light of the present observations on their kidney function. It has been emphasized that no difference has been found between oedematous and ' normal' infants in this respect, except for the very small urine output of the former. When, however, the kidney function of premature, full-term infants, and adults was compared it was found that all infants, but particularly premature infants, had very low sodium and chloride clearances. More than that, evidence was obtained that premature infants probably reabsorbed more sodium and chloride per c.c. of glomerular filtrate than full-term infants, and these again than adults. A restricted output of salt goes naturally with a tendency towards water retention and consequently towards small urine volumes. This then is the reason why all premature babies are susceptible to oedema, but the low level of protein in the plasma may also be a contributory cause. The individual idiosyncrasies which determine the development of oedema may be very slight, and have so far escaped detection.

The causes of the low mineral clearances were discussed in the article on full-term infants. It was suggested that a low glomerular filtration rate, combined with an overactive suprarenal cortex might account for the findings. It was recognized, however, that the low potassium clearances could not be so explained. A better explanation now seems to be that the salt retention, water retention and oedema may be due to some over-action of the female sex hormones which can certainly produce these effects without, it seems, altering the potassium metabolism (Thorn and Emerson, 1940). The retention of sodium, chloride, and water in infancy is perhaps to be correlated with the well-known fact that at this age all infants contain more sodium and chloride per kgm. of body weight than adults (Shohl, 1939). The low mineral clearances may also be regarded as a protective mechanism, for the mineral intake of breast-fed infants is small while their rate of growth is rapid. 
Gruenwald, P., and Popper, H. (1940). J. Urol., 43, 452.

Hallum, J. L. (1941). M.D. Thesis, Univ. St. Andrew"s.

Hickmans, E. M. (1940). Personal communication.

Kaplan, B. I., and Smith, H. W. (1935). Amer. J. Physiol., 113, 354.

McCance, R. A., and Young, W. F. (1941). J. Physiol., 99, 265.

Mello-Leitao (1916). Amer. J. Dis. Child., 11, 214.

Peters, J. P., and Van Slyke, D. D. (1922). Quantitative clinical chemistry, Baltimore, 2.

von Reuss, A. (1913). Verh. Ges. Kinderheilk., 29, 145; quoted from Hess, J. H. (1922). Premature and congenitally diseased infants, Phila.

Shannon, J. A., and Winton, F. R. (1940). J. Physiol., 88, 97.

Shohl, A. T. (1939). Mineral metabolism, New York.

Thorn, G. W., and Emerson, K. (1940). Ann. intern. Med., 14, 767.

Wilkinson, B. M., and McCance, R. A. (1940). Quart. J. exp. Physiol., 30, 249. 